\title{
透析患者における動静脈シャントの皮膚微小循環に及ぼす影響
}

\author{
丸山 圭史 青木 正* 馬㴊 非砂夫 垣 内 孟 \\ 中橋 弥光* \\ 西陣病院内科，同泌尿器科*
}

（昭和 63 年 11 月 1 日受付）

key words：レーザードップラー血流計，皮膚微小循環，動静脈シャント，血液透析

〈要旨〉

ブラッドアクセス $(\mathrm{BA})$ が，その周辺部の局所皮膚微小循環に及ぼす影響を検討するため，レーザードップラー血 流計 TSI LASERFLO® blood perfusion monitor (BPM 403) を用いて皮膚微小血管血流量 (cutaneous microvascular blood flow, CMBF) を測定した，対象は control として健常者 10 例と，前腕に動静脈内シャントを作成した透 析 (HD) 患者 10 例 (男 3，女 7 )で, うち 2 例は過剩環流による BA 側の手の腫大を呈していた。BA側及び反対 (NBA) 側の手背中央部にて, 安静仰臥位で HD 前, HD 開始 1 及び 2 時間後, HD 終了後に各々測定し, 以下の結果を得た。

1) 手の腫大を有する 2 例を含む 4 例では, HD 前に NBA 側 $(1.62-4.21 \mathrm{ml} / \mathrm{min} / 100 \mathrm{cc})$ に比べ BA 側 $(6.36$ -30.7 ml/min $/ 100 \mathrm{cc}$ ) の著明な CMBF の増大を認めた。これは HD 中，徐々に減少したが，うち 3 例で HD 開始 1 時間後に一過性の増大を認めた。 また手の腫大を有する 2 例では HD 終了後の BA 側の CMBF は, NBA 側の約 3.3 倍, 7.3 倍ときわめて高值であったが, 他の 2 例は 1.4 倍, 1.7 倍であった。

2 ) 残りの 6 例の HD 前の CMBF は, BA 側 3.09-5.30 ml/min/100 cc, NBA 側 $1.57-5.05 \mathrm{ml} / \mathrm{min} / 100 \mathrm{cc}$ と同 程度で, HD 中もほぼ不変であった。

3) HD 患者の NBA 側の CMBF は, 健常群 (1.10-4.34 ml $/ \mathrm{min} / 100 \mathrm{cc})$ と比べて有意差がなく，またこれらの CMBF と末梢静脈へマトクリット值の間には有意な相関はなかった。

以上の結果より，BA 側の手背の CMBF の増大は主として BA 作成による動脈血の大量流入によることが明らか で， その測定は BA による過剩環流の治療と予防に有意義であると思われた。

\section{Effect of arteriovenous fistula on cutaneous microvascular circulation in hemodialysis patients}

Yoshifumi Maruyama, M.D., Tadashi Aoki, M.D.*, Hisao Mabuchi, M.D., Takeshi Kakiuchi, M.D., Hisamitsu Nakahashi, M.D*

Department of Internal medicine and department of Urology*, Nishijin Hospital, Kyoto

Cutaneous microvascular blood flow (CMBF) was measured by laser Doppler flowmetry, to examine the effect of blood access (BA) on cutaneous microvascular circulation. We studied 10 normal subjects and 10 hemodialysis (HD) patients (male 3, female 7) who had arteriovenous shunt on the right or left forearm. Two patients showed luxurious perfusion. We made flow measurements in the center of the back of both hands in the resting supine position before and after HD, and 1 and 2 hours after HD started.

1) CMBF on the BA side $(6.36-30.7 \mathrm{ml} / \mathrm{min} / 100 \mathrm{cc})$ was markedly higher than on the non-BA side $(1.62-$ $4.21 \mathrm{ml} / \mathrm{min} / 100 \mathrm{cc}$ ) in 4 patients, including 2 with swollen hands. This increased flow gradually decreased during $H D$, but 3 of the 4 patients showed transient elevation 1 hour after HD started. Of these 4 patients, the CMBF after $\mathrm{HD}$ on the BA side in the 2 patents with swollen hands were 3.3 and 7.3 times greater than on the non-BA side, but in the other 2 patients, they were 1.4 and 1.7 times.

丸山 圭史 西陣病院内科

干 602 京都市上京区五辻通六軒町西入溝前町 $1035(075-461-8800)$
2) The CMBF before $H D$ in the remaining 6 patients ranged from $3.09-5.30 \mathrm{ml} / \mathrm{min} / 100 \mathrm{cc}$ on the non-BA side and $1.57-5.05 \mathrm{ml} / \mathrm{min} / 100 \mathrm{cc}$ on the non-BA 
side, and it did not change during HD.

3) There was no significant difference in CMBF on the non-BA side between the patients and normal subjects $(1.10-4.34 \mathrm{ml} / \mathrm{min} / 100 \mathrm{cc})$, and no correlation between CMBF and peripheral venous hematocrit.

It is suggested that the increase in CMBF on the BA side depends on the massive inflow of arterial blood through the $B A$, and the measurement of CMBF is useful for the treatment and prevention of luxurious perfusion induced by $B A$.

\section{緒言}

長期血液透析 (HD) 患者の合併症の一つとして，前腕 に動静脈 (AV) 内シャントを作成している場合, blood access (BA) 側の著明な手の腫大をきたすことがある。 これは動脈血の前腕遠位部への過剰血流による venous hypertention が原因とされている ${ }^{1}$ が，微小血管レベル での血液循環についてはな扔不明な点も多い。今回我々 は AV シャントによる BA が，その周辺部の局所皮膚 微小循環に及ぼす影響を検討するために，レーザードッ プラー血流計を用いて皮盧微小血管血流量（cutaneous microvascular blood flow, CMBF) を測定した。

対象

対象は BA 側に著明な手の腫大を有する 2 例を含む $\mathrm{HD}$ 患者 10 例（男 3 ，女 7 ）で，年齢は $37 \sim 78$ 歳，平 均 63.6 歳。原疾患は慢性腎炎 8 例, 糖尿病 2 例。 $\mathrm{HD}$ 期 間及び BA 使用期間は $4 \sim 122$ か月, 平均 33〜 34 か月. $\mathrm{BA}$ 作成部位は右或いは左前腕橈側で，AV を側々吻合 した。HD 時間は 5 時間，週 3 回，HD 前体重は 38〜56 $\mathrm{kg}$, 平均 $45.6 \mathrm{~kg}$, 末梢静脈へマトクリット (Ht) は 17.2 31.2, 平均 22.2 であった。また健常者 10 例（男 5，女 5 ) を control とし，その年齢は 19〜36 歳，平均 25.6 歳, 体重 $45 \sim 74 \mathrm{~kg}$, 平均 $59.2 \mathrm{~kg}$, Ht $36.2 \sim 50.6$, 平 均 44.1 であった。

\section{方法}

レーザードップラー血流計 TSI LASERFLO® blood perfusion monitor (BPM 403) を用い，明らかに可視で きる血管を避けてほぼ手背中央部の皮膚上で安静仰臥位 にて CMBF を測定した。HD 群では BA 側及び反対 (NBA) 側で HD 開始前， 1 及び 2 時間後，5時間 HD 終了後に各々 3 回測定し平均值を求めた。また健常群で は 5 分間安静臥床を保った後，左右で各々 3 回測定し平 均值を求めた。図 1 が血流計本体, 図 2 が皮膚血流测定 用プローブである。原理は皮下 1〜1.5 mm の深さで, sampling volume 1〜1.5 $\mathrm{mm}^{3}$ の中の毛細血管内を移動 する赤血球に近赤外 $780 \mathrm{~mm}$ の波長のレーザー光をあ て，反射光によるドップラーシフトを計測し血流を求め るものである。測定值は組織 $100 \mathrm{cc}$ 中の 1 分間の血流量 として表示され，最小值は 0.001 ，時間分解能は 100 msec である。

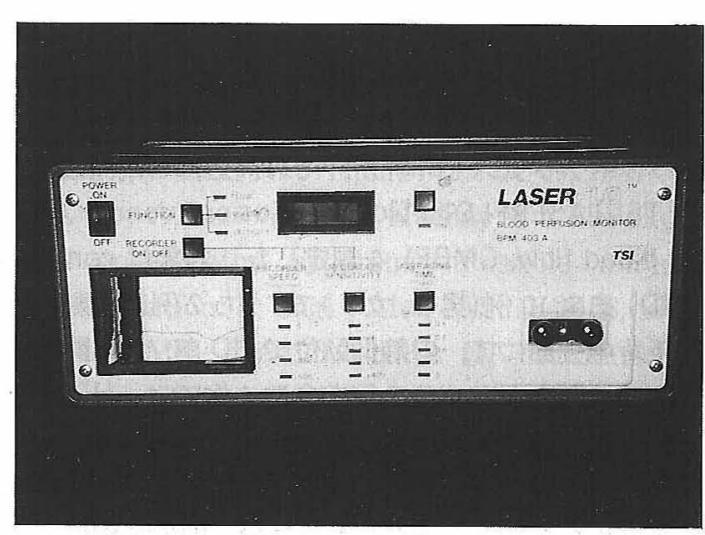

図 1 今回用いたレーザードップラー血流計本体 を示す。

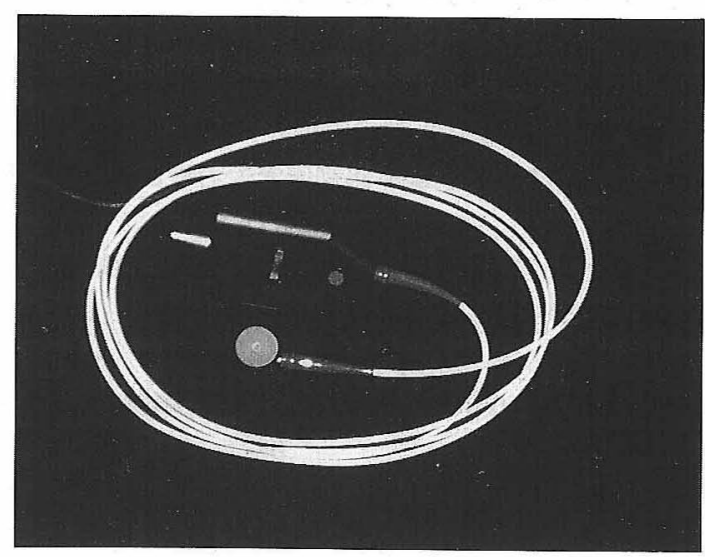

図 2 皮膚微小血管血流測定用プローブを示す。

\section{結果}

図 3 に健常例及び HD 前後の結果を示す。まず健常群 の $\mathrm{CMBF}$ では右 $(2.99 \pm 1.08 \mathrm{ml} / \mathrm{min} / 100 \mathrm{cc})$ は左 $(1.96 \pm 1.00 \mathrm{ml} / \mathrm{min} / 100 \mathrm{cc})$ より有意に大であったが性 差は認めなかった。また $\mathrm{HD}$ 群の $\mathrm{CMBF}$ は，症例によ り HD 前の BA 側 $(3.09-30.7 \mathrm{ml} / \mathrm{min} / 100 \mathrm{cc})$ のばらつ きが大きく，NBA 側 $(1.57-5.05 \mathrm{ml} / \mathrm{min} / 100 \mathrm{cc})$ と比べ 有意差を認めなかった。また $\mathrm{HD}$ 前後においても $\mathrm{BA}$ 側 及び NBA 側とも有意な変化はなかった。さらに透析後 の NBA 側の血流 $(3.45 \pm 0.93 \mathrm{ml} / \mathrm{min} / 100 \mathrm{cc})$ は, control の左右とも有意差がなかった。 


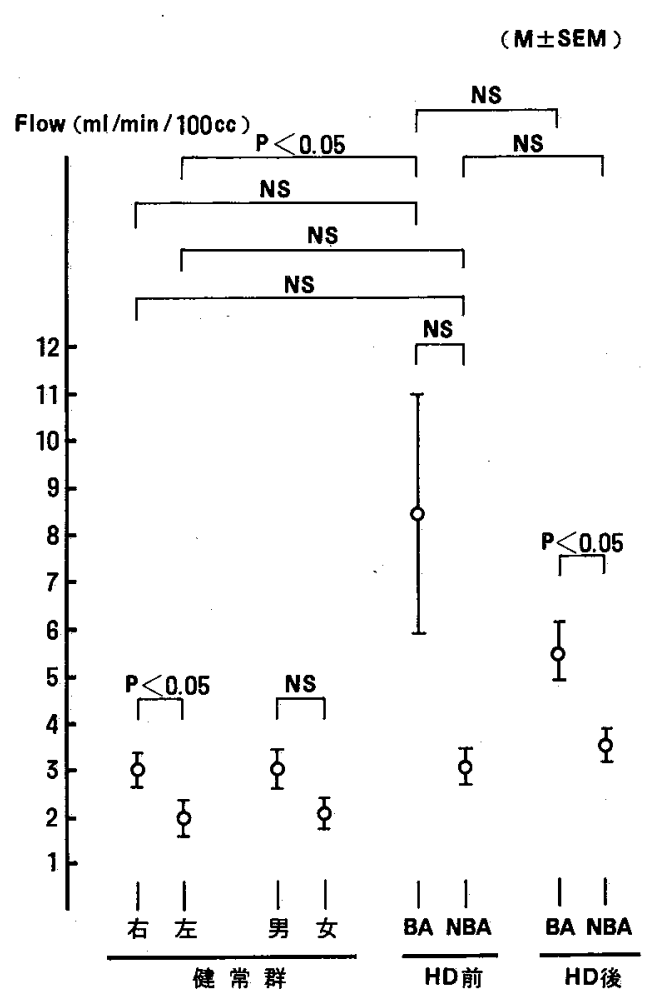

図 3 健常群と透析群の皮鬳微小血管血流量の比 較を示す。略語は $\mathrm{HD}$ (血液透析), BA (Blood access 側), NBA (Blood access 反対側).

次に図 4 に各症例別の HD 中の変化を示す。まず症例 $1 \sim 4$ の BA 側の $\mathrm{HD}$ 前 $\mathrm{CMBF}$ は, NBA 側に比し約 5 倍以上であった.また症例 $2 \sim 4$ では HD 1 時間後に むしろ増加したが，以後 $\mathrm{HD}$ 経過につれ減少する傾向を 示した。しかし症例 1 4の $\mathrm{HD}$ 終了後の BA 側と $\mathrm{NBA}$ 側の $\mathrm{CMBF}$ 比は各々 1.7，3.3，7.3，1.4で特に 手の腫大を認めた症例 2，3で高值であった。な拉糖尿 病の 2 例を含む症例 $5 \sim 10$ では BA 側と NBA 側の $\mathrm{CMBF}$ に顕著な差はなく, HD 中もほぼ不変であった。 次に HD 群の NBA 側と健常群の右或いは左の CMBF を用いて Ht との関係をみたが，いずれも有意な相関は なかった（図 5 ).

考察

レーザードップラー血流計は, 1972 年, Riva $ら^{2)} に よ$ り臨床応用されて以来，今日まで皮膚党をはじめとして 各種臓器における微小血管血流の体位 ${ }^{4)}$, 運動 ${ }^{5)}$, 手術 ${ }^{6,7,8)}$ による変化や温熱9), 薬物 ${ }^{10)}$ による影響が報告されてい る。本研究で用いた LASERFLO®は, 特に血流が絶対 值として計測できる利点があり ${ }^{11,12)}$ ，今後さらに幅広い 活用が期待されるものと思われる。

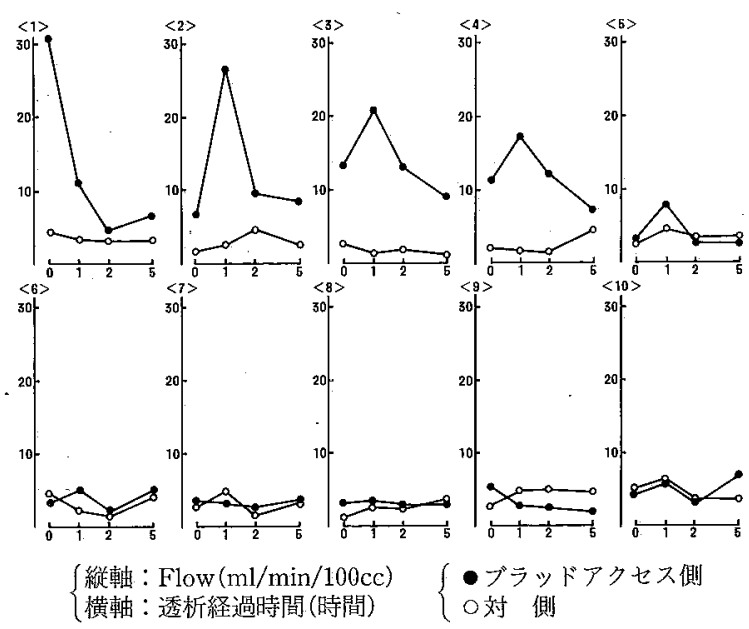

図 4 透析中の各症例の皮膚微小血管血流変化を 示す. 症例 2,3 はシャント側に著明な手 の腫大を有する患者で, 症例 6,10 は糖尿 病患者である。

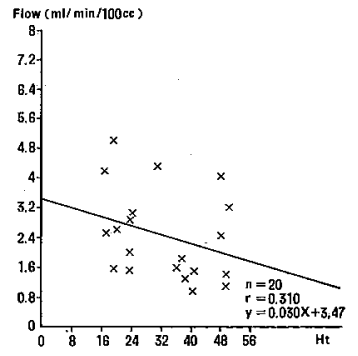

1) 健常群(左)及びHD群 (NBA)

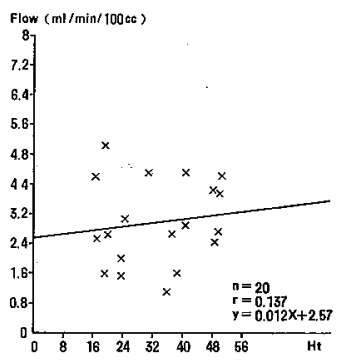

2) 健常群(右)及びHD群 (NBA)
図 5 皮膚微小血管血流量と末梢静脈へマトク リット值との関係を示す。略語は図 3 と同 様。

さて, 今回の測定結果から， $\mathrm{BA}$ 側の $\mathrm{CMBF}$ が増大 しているグループとほとんど左右差のないグループに分 類することが可能であった。まず左右差のないグループ では，BA 側の CMBF は NBA 側と同様に本来の毛細 血管血流を示すものと思われる。むしろ BA 作成のた め，シャントより遠位部の動脈血流が低下し，その領域 の CMBF の低下が生じる可能性も考えられるが，実際 には尺骨動脈より流入する血流のため実際にはほとんど 変化しないと思われる。

一方， BA 側の $\mathrm{CMBF}$ が著明に増大しているグルー プでは，BA を介して動脈化した静脈より多量のシャン 卜血流が手背の毛細血管に逆流していると思われた。逆 に，この増大した血流が HD とともに減少した事実か ら, 循環血流量減少によるシャント血流の減少が推定さ 
れる、ただ $\mathrm{HD}$ 開始 1 時間後に血流の一過性増大をみた 症例があり，その原因として HDによる未梢血管拡張， 動脈化した静脈血管内圧低下による一過性のシャント血 流の増大，穿刺部との位置関係によりシャント周辺部静 脈から BA への逆流による手背部静脈の血流増加等の 可能性が推測された.

また,これまで BA 側の手の腫大の原因としては, 種々の局所的条件に加えて, 中枢側への血流障害による 末梢静脈への過剩環流が指摘されている1占が，今回の検 討でも HD 終了後の CMBF は $\mathrm{BA}$ 側の方が NBA 側に 比べて著明に多く，毛細血管レベルでも血流が増加して いることが確認された。即ち，増加した血流により，固 有の毛細血管の血流分布や方向性が著明に変化し, 中枢 側への血流障害が末梢静脈レベルのみならず毛細血管レ ベルでも生じている可能性が示唆された。従って HD 患 者の CMBF の測定はシャントによる手背部末梢の血流 状態を知り, 手の腫大等の合併症を治療及び予防する上 できわめて有用であると思われた。

なお, plethysmographを用いた研究によると，NBA 側の指の血流量は HD により増加するといわれており， その原因として venous occlusion method を用いた研究 から末梢血管抵抗の減少が報告されている ${ }^{13)}$.しかし, 今 回測定した CMBF ではそのような変化は認められな かった.

また, 今回の $\mathrm{HD}$ 患者の NBA 側の $\mathrm{CMBF}$ は, これ まで報告された健常者の $\mathrm{CMBF}^{4,12)}$ と比べて大差なく, しかも健常者を含めて検討した結果, 未梢静脈 $\mathrm{Ht}$ と $\mathrm{CMBF}$ に有意な相関はなかった。しかしレーザードップ ラー血流計は, 元来毛細血管内を移動する赤血球を測定 対象としているため，その測定值は理論的には，毛細血 管 $\mathrm{H}^{14 \sim 16)}$ ，赤血球の形態 ${ }^{17)}$, HD 中の hemoconcentra-

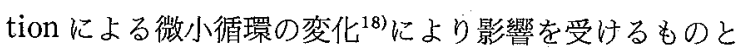
思われる，さらに，その測定值にはきわめて個体差があ り，しかもわずかな測定条件の変化により大きく左右さ れるため, 厳密な基準值の決定がなかなか困難である。 従って今後, 微小循環動態に影響を与える種々の因子に 関する補正係数と基準值について詳細な検討が必要であ ると思われた。

\section{結語}

1) レーザードップラー血流計を用いて，前腕に $\mathrm{AV}$ シャントを作成した HD 患者の手背の CMBF を測定し た。

2) HD 患者 10 例中 4 例では HD 前に，NBA 側に 比へ $\mathrm{BA}$ 側の著明な $\mathrm{CMBF}$ の増大を認め, これらは HD 経過中, 減少する傾向を示した.

3 ) $\mathrm{HD}$ 患者の NBA 側の CMBF は健常群と有意差
がなかった。

4) BA 側の血流の増大は, 主としてシャント作成に よる動脈血の大量流入によることが明らかで，その測定 は過剰環流の治療と予防に有意義であると思われた。

要旨は第 33 回日本透析療法学会総会で発表した。

\section{文献}

1) 太田和夫：ブラッドアクセスの外科的合併症とその 処置, ブラッドアクセス一作り方と使い方一： 217-285, 南江堂, 東京, 1982

2) Riva C, Ross B, Benedek G : Laser doppler measurements of blood flow in capillary tubes and retinal arteries. Invest Opthalmol $11: 936-944$, 1972

3) Nilsson GE, Tenland T, Öberg P \& : A new instrument for continuous measurement of tissue blood flow by light beating spectroscopy. IEEE Trans Biomed Eng BME-27 : 12-19, 1980

4) Winsor T, Haumschild DJ, Winsor DW, Wang $Y$, Luong TN : Clinical application of laser Doppler flowmetry for measurement of cutaneous circulation in health and disease. Angiology $38: 727-736$, 1987

5) Taylor WF, Johnson JM, Kosiba WA, Kwan $\mathrm{CM}$ : Graded cutaneous vascular responses to dynamic leg exercise. J Appl Physiol 64: 1803 $-1809,1988$

6) Rosenblum BR, Bonner RF, Oldfield EH : Intraoperative measurement of cortical blood flow adjacent to cerebral AVM using laser doppler velocimetry. J Neurosurg $66: 396-399,1987$

7) R S Chung: Blood flow in colonic anastomoses, effect of stapling and suturing. Ann Surg 206: 335 $-339,1987$

8) Jenkins SD, Sepka RS, Barwick WJ, Serafin D, Klitzman B : Routine clinical use of laser doppler flowmeter to monitor free tissue transfer. J Reconstructive Microsurg 87 : 281-283, 1987

9) Song CW, Rhee JG, Haumschild DJ : Continuous and non invasive quantification of heat-induced changes in blood flow in the skin and RIF-1 tumor of mice by laser Doppler flowmetry. Int J Hyperthermia $3: 71-77,1987$

10) Druce HM, Bonner RF, atow $C P$, Choo P, Summers RJ, Kaliner MA : Response of nasal blood 
flow to neurohormones as measured by laserdoppler velocimetry. J Appl Physiol : Respirat Environ Exercise Physiol 57 : 1276-1283, 1984

11) Calibration verification of TSI LASERFLO ${ }^{\circledR}$ BPM 403. 1986, TSI Incorporated, St. Paul.

12) Haumschild DJ : Microvascular blood flow measurement by laser Doppler flowmetry. TSI APPLICATION NOTE 1986

13）織笠長俊：血液透析時に扝ける末梢血行諸量の変 化. 岩手医誌 $38 ： 209-223 ， 1986$

14) Gaehtgens $P$ : 'Regulation' of capillary haemotocrit. Int J Microcirc : Clin Exp 3 : 147-160, 1984

15) Linderkamp O, Versmold HT, Strohhacker I, Messow-Zahn K, Riegel KP, Betke K : Capillary -venous hematocrit differences in newborn infants. Eur J pediatr $127: 9-14,1977$

16) Mchedlishvili G, Varazashvili $M:$ Hematocrit in cerebral capillaries and veins under control and ischemic conditions. J Cereb Blood Flow Metab $7: 739-744,1987$

17) Rodgers GP, Schechter AN, Noguchi CT, Klein HG, Nienhuis AW, Bonner RF: Periodic microcirculatry flow in patients with sickle-cell disease. N Eng J Med 311 : 1534-1538, 1984

18) Vicaut E, Stucker O, eisseire BT, uvelleroy MD : Effects of changes in systemic hematocrit on the microcirculation in rat cremaster muscle. Int $\mathrm{J}$ Microcirc : Cin Exp $6: 225-235,1987$ 